Perwira Journal of Economics and Business (PJEB)

E-ISSN : 2775-572X

Volume 1 Nomor 1

Februari 2021

\title{
KONTRIBUSI TINGKAT INDUSTRI TERHADAP ANGKATAN KERJA DI KABUPATEN PURBALINGGA
}

\author{
Aji Priambodo', Reza Rahardi Hasibuan² Maman Sulaeman ${ }^{3}$ Dinnas Purnomo $^{4}$ \\ ${ }^{1,2,3,4}$ Universitas Perwira Purbalingga \\ Email Koresponden. ajipriambodo@unperba.ac.id
}

\begin{abstract}
Purbalingga Regency is a regency in Central Java, which occupies the 5th place with high poverty. The problem of poverty is the main problem faced by the regency of Purbalingga. The question of poverty is also closely related to the limitations in the world of employment. This research aims to analyse industry-level influence on the workforce in Purbalingga district. In this study used research object in Purbalingga district. And is a type of quantitative descriptive research (secondary) and the data used comes from websites and books in numbers in the Central Statistic Agency (BPS) Purbalingga district. In this study the number of samples used is industrial level data and discussion in Purbalingga District and used in 2009-2019. The method of econometrics analysis used is linear regression. The results showed that the industrial level has an impact of $45.2 \%$ on the workforce in Purbalingga district
\end{abstract}

Keywords: unemployment, industry, poverty

\section{PENDAHULUAN}

Pembangunan adalah proses perubahan yang direncanakan untuk memperbaiki berbagai aspek kehidupan masyarakat guna mewujudkan peningkatan kesejahteraan dan kualitas kehidupan masyarakat. Besarnya kompleksitas permasalahan pembangunan akibat terus bertambahnya tantangan, dinamika lingkungan internal maupun eksternal, serta adanya pergeseran standar atau ukuranukuran mengenai kualitas hidup dan kesejahteraan masyarakat, menyebabkan upaya pembangunan menjadi suatu proses yang harus terus menerus dilakukan. Sejalan dengan dinamika otonomi daerah, beban dan tanggung jawab Pemerintah Daerah untuk meningkatkan kualitas hidup dan kesejahteraan masyarakat, serta meningkatkan kualitas pelayanan publik menjadi semakin berat. Di sisi lain, daerah dihadapkan pada berbagai kendala antara lain terbatasnya ketersediaan sumberdaya pembangunan terutama sumberdaya finansial. Dengan permasalahan dan tantangan tersebut, maka penyelenggaraan pembangunan daerah harus dilaksanakan secara sistematis, terarah, dan berkelanjutan sehingga dapat mencapai tujuan dan sasaran yang telah ditetapkan dengan memanfaatkan sumberdaya yang tersedia secara efektif dan efisien. Pada negara yang sedang berkembang umumnya masalah pengangguran merupakan problema yang sulit dipecahkan hingga kini, karena masalah pengangguran menyebabkan tingkat pendapatan nasional dan tingkat kemakmuran masyarakat tidak mencapai potensi maksimal, seperti halnya juga di Indonesia, pemerintah mengupayakan berbagai jalan keluar untuk mengatasi pengangguran secara lambat laun baik di perkotaan dan di pedesaan.

Banyak tenaga kerja yang tersedia tetapi tidak dapat diserap oleh industri hal ini dikarenakan keahlian tenaga kerja tidak sesuai dengan yang dibutuhkan oleh industri, di sinilah perlunya peranan pemerintah untuk melakukan pendidikan atau pelatihan terhadap tenaga kerja agar memiliki skill yang dibutuhkan oleh industry. 
Kabupaten Purbalingga merupkana Kabupaten di Jawa Tengah yang menduduki posisi ke 5 Kabupaten dengan angka kemiskinan yang tinggi. Masalah kemiskinan ini merupakan masalah utama yang dihadapi oleh Kabupaten Purbalingga. Persoalan kemiskinan ini juga berkaitan erat dengan adanya keterbatasan di dalam dunia lapangan pekerjaan. Adanya keterbatasan lapangan pekerjaan ini membuat banyak masyarakat Kabupaten Purbalingga yang tidak bekerja atau tidak memiliki pekerjaan yang biasa disebut sebagai pengangguran. Pengangguran yang dialami oleh sebagian masyarakat inilah yang membuat mereka kesulitan dalam memenuhi kebutuhan hidupnya sehingga angka kemiskinan selalu ada dan tinggi.

Struktur lapangan usaha sebagian masyarakat Kabupaten Purbalingga telah bergeser dari lapangan usaha Pertanian, Kehutanan, dan Perikanan ke lapangan usaha ekonomi lainnya yang terlihat dari penurunan peranan setiap tahunnya terhadap pembentukan PDRB Kabupaten Purbalingga.

\section{LITERATUR REVIEW}

Permintaan tenaga kerja berkaitan dengan perencanaan tenaga kerja yang merupakan suatu rencana yang memuat pendayagunaan tenaga kerja yang optimum, efisien dan produktif guna mendukung pertumbuhan ekonomi sosial secara nasional, sektoral dan regional yang bertujuan untuk mengurangi pengangguran dan meningkatkan kesejahteraan pekerja.Nicholson dan College (1995) berasumsi bahwa setiap perusahaan akan berusaha untuk memaksimumkan keuntungan atau laba dengan memperbanyak tenaga kerja untuk dipekerjakan, dan hal ini berdasarkan dua alasan: pertama, apabila input lain relatif lebih mahal maka diganti dengan tenaga kerja yang lebih murah. Kedua, apabila terjadi penurunan upah yang dimana itu bisa mengurangi biaya marjinal, maka memungkinkan perusahaan untuk meningkatkan output dan menaikkan penggunaan seluruh input termasuk tenaga kerja. Sedangkan Simanjuntak (1985) juga berasumsi bahwa pengusaha akan menambah tenaga kerjanya tergantung dari pertambahan permintaan masyarakat terhadap barang yang diproduksinya, dan itu disebut "derived demand". Ekonom klasik juga mengasumsikan bahwa yang mempengaruhi penyediaan atau penawaran tenaga kerja adalah apabila tingkat upah bertambah, sebaliknya dengan bertambah atau meningkatnya tingkat upah maka permintaan terhadap tenaga kerja akan berkurang (Simanjuntak, 1985). Hal ini digambarkan dengan garis SS dan garis DD pada gambar berikut:

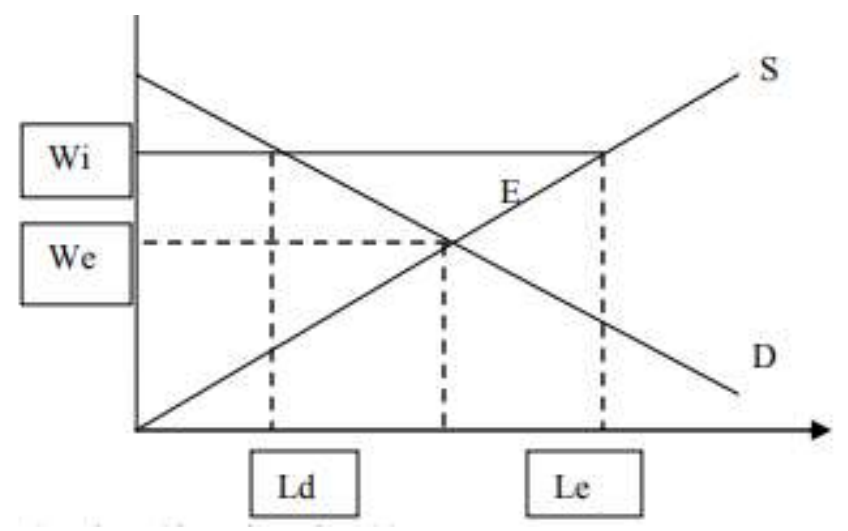

Gambar diatas menjelaskan bahwa titik $E$ adalah titik ekuilibrium yaitu keadaan dimana penyediaan tenaga kerja sama dengan permintaan, tidak terjadi pengangguran. Diasumsikan bahwa semua pihak mempunyai informasi yang lengkap, sehingga teori neoklasik beranggapan bahwa jumlah penyediaan tenaga kerja sama dengan permintaan tenaga kerja. Akan tetapi dalam kenyataan, titik ekuilibrium itu tidak pernah tercapai karena informasi yang didapat tidak pernah $\mathrm{W}$ Wi We Ld Le Tenaga Kerja, Penempatan, Penganggur sempurna dan hambatan-hambatan institusional selalu ada dan pada umumnya upah yang berlaku (Wi) lebih besar dari upah ekuilibrium (We), sehingga yang terjadi adalah perusahaan mengurangi permintaan akan tenaga kerja dan oleh sebab itu terjadilah pengangguran karena meningkatnya penawaran tenaga kerja. 
Secara umum, pertumbuhan unit usaha pada suatu sektor produksi pada suatu wilayah akan menambah jumlah tenaga kerja. Jumlah unit usaha mempunyai pengaruh yang positif terhadap jumlah tenaga kerja.Artinya jika jumlah unit usaha bertambah maka jumlah tenaga kerja yang dibutuhkan oleh unit usaha yang bersangkutan akan bertambah pula (Squire, 1992). Dalam perekonomian makro kenaikan nilai investasi akan meningkatkan permintaan agregat dan pendapatan nasional. Lalu peningkatan dalam permintaan agregat akan membawa perubahan pada kapasitas produksi suatu perekonomian yang kemudian akan diikuti oleh pertambahan dalam kebutuhan akan tenaga kerja untuk proses produksi,yang menandakan bertambahnya lapangan pekerjaan (Sukirno, 2002).

Tinggi rendahnya jumlah tenaga kerja yang diminta oleh pengusaha dipengaruhi oleh tinggi rendahnya jumlah barang yang diproduksi oleh tenaga kerja tersebut.Tinggi rendahnya barang yang diproduksi tergantung kepada tinggi rendahnya permintaan oleh konsumen. Semakin tinggi jumlah barang yang diminta oleh konsumen semakin tinggi jumlah barang yang diproduksi sehingga semakin tinggi pula jumlah tenaga kerja yang diminta oleh perusahaan tersebut (Simanjuntak, 2010: 83). Beberapa penelitian terdahulu telah mendukung pernyataan tersebut. Karib (2012) dalam penelitiannya mengenai sektor industri di Sumatera Barat menemukan bahwa nilai produksi,nilai investasi,dan jumlah unit usaha merupakan faktor yang mempunyai pengaruh yang signifikan terhadap perubahan jumlah tenaga kerja yang terserap pada sektor industri di Sumatera Barat. Diofandrew (2015) pada penelitian di Kota Kediri menemukan bahwa variabel tingkat pertumbuhan PDRB pertumbuhan sektor industri berpengaruh signifikan negatif terhadap penyerapan sektor industri di kota Kediri. Variabel investasi berpengaruh signifikan negatif terhadap penyerapan tenaga kerja sektor industri di Kota Kediri.
Sehingga ketika investasi naik maka tidak diikuti dengan penyerapan tenaga kerja sektor industri di kota Kediri. Variabel Unit Usaha sektor industri berpengaruh signifikan positif terhadap penyerapan tenaga kerja sektor industri di kota Kediri. Prabandana (2015) dalam penelitiannya pada industri kecil di Kabupaten Sukoharjo menemukan bahwa modal tidak berpengaruh secara signifikan terhadap penyerapan tenaga kerja pada sektor industri kecil di Kabupaten Sukoharjo. Nilai produksi berpengaruh positif signifikan terhadap penyerapan tenaga kerja pada sektor industri kecil di Kabupaten Sukoharjo. Tingkat upah berpengaruh negatif signifikan terhadap penyerapan tenaga kerja pada sektor industri kecil di Kabupaten Sukoharjo.

$$
\text { Munasriah (2015) dalam }
$$

penelitiannya pada industri kecil di Kabupaten Wajo menemukan bahwa jumlah unit usaha berpengaruh positif dan signifikan secara langsung terhadap penyerapan banyaknya tenaga kerja. Secara tidak langsung jumlah unit usaha berpengaruh negatif terhadap penyerapan tenaga kerja melalui output sektor industri. Investasi berpengaruh positif dan signifikan secara langsung terhadap penyerapan tenaga kerja. Secara tidak langsung investasi berpengaruh negatif terhadap penyerapan tenaga kerja melalui output sektor industry.

\section{METODE PENELITIAN}

Pada penelitian ini digunakan objek penelitian di kabupaten Purbalingga. Dan merupakan jenis penelitian deskriptif kuantitatif (sekunder) dan data yang digunakan berasal dari website dan buku dalam angka di Badan Pusat Statistik (BPS) kabupaten Purbalingga. Dalam penelitian ini jumlah sampel yang digunakan adalah data tingkat industri dan penganguran di kabupaten Purbalingga dan digunakan tahun 2009-2019. Metode analisis ekonometrika yang digunakan adalah regresi linear. 
HASIL PENELITIAN DAN PEMBAHASAN

Berikut ini penulis deskipsikan tingkat industry di Kabupaten Purbalingga tahun 2009-2019.

Tabel 1

Tingkat Industri di Kabupaten Purbalingga

\begin{tabular}{|c|c|c|r|}
\hline No & Tahun & $\begin{array}{c}\text { Tingkat } \\
\text { Industri }\end{array}$ & \multicolumn{1}{c|}{+ /- } \\
\hline 1 & 1999 & 9,960 & - \\
\hline 2 & 2000 & 9,037 & -10.21 \\
\hline 3 & 2001 & 9,916 & 8.86 \\
\hline 4 & 2002 & 12,156 & 18.43 \\
\hline 5 & 2003 & 12,143 & -0.11 \\
\hline 6 & 2004 & 13,182 & 7.88 \\
\hline 7 & 2005 & 14,375 & 8.30 \\
\hline 8 & 2006 & 14,050 & -2.31 \\
\hline 9 & 2007 & 24,812 & 43.37 \\
\hline 10 & 2008 & 26,983 & 8.05 \\
\hline 11 & 2009 & 29,851 & 9.61 \\
\hline 12 & 2010 & 32,884 & 9.22 \\
\hline 13 & 2011 & 35,803 & 8.15 \\
\hline 14 & 2012 & 35,803 & 0.00 \\
\hline 15 & 2013 & 43,568 & 17.82 \\
\hline 16 & 2014 & 42,397 & -2.76 \\
\hline 17 & 2015 & 47,535 & 10.81 \\
\hline 18 & 2017 & 48,932 & 2.85 \\
\hline 19 & 2018 & 50,346 & 2.81 \\
\hline 20 & 2019 & 51,749 & 2.71 \\
\hline
\end{tabular}

Sumber: BPS Purbalingga, 2020

Berdasarkan data diatas terlihat bahwa tingkat industri di Kabupaten Purbalingga fluktuatif, pada tahun 2000 angka pengangguran turun sampai $10,21 \%$ namun tahun 2001 meningkat lagi 8,86\% demikian pula dengan tahun-tahun berikutnya

Tabel 2

Angka Pengangguran Di Kabupaten Purbalingga

\begin{tabular}{|c|c|c|c|}
\hline No & Tahun & Pengangguran & \multicolumn{1}{|c|}{+ - } \\
\hline 1 & 1999 & 15,391 & - \\
\hline 2 & 2000 & 7,531 & -104.37 \\
\hline
\end{tabular}

\begin{tabular}{|c|c|c|c|}
\hline 3 & 2001 & 14,543 & 48.22 \\
\hline 4 & 2002 & 18,564 & 21.66 \\
\hline 5 & 2003 & 14,796 & -25.47 \\
\hline 6 & 2004 & 19,202 & 22.95 \\
\hline 7 & 2005 & 15,447 & -24.31 \\
\hline 8 & 2006 & 17,187 & 10.12 \\
\hline 9 & 2007 & 32,008 & 46.30 \\
\hline 10 & 2008 & 29,058 & -10.15 \\
\hline 11 & 2009 & 19,638 & -47.97 \\
\hline 12 & 2010 & 16,653 & -17.92 \\
\hline 13 & 2011 & 24,048 & 30.75 \\
\hline 14 & 2012 & 24,218 & 0.70 \\
\hline 15 & 2013 & 26,186 & 7.52 \\
\hline 16 & 2014 & 23,782 & -10.11 \\
\hline 17 & 2015 & 21,858 & -8.80 \\
\hline 18 & 2017 & 26,138 & 16.37 \\
\hline 19 & 2018 & 29,522 & 11.46 \\
\hline 20 & 2019 & 22,789 & -29.54 \\
\hline
\end{tabular}

Sumber: BPS Purbalingga, 2020

Berdasarkan data diatas terlihat bahwa angka pengangguran di Kabupaten Purbalingga fluktuatif, pada tahun 2000 angka pengangguran turun sampai 104,37\% namun tahun 2001 meningkat lagi 48,22\% demikian pula dengan tahun-tahun berikutnya. Menurut Sakernas, pengangguran mencakup mereka yang mencari pekerjaan, sedang mempersiapkan usaha baru, dan mereka yang tidak mencari pekerjaan karena putus asa sudah berkalikali mencari pekerjaan namun belum berhasil.

Hasil analisis data diperoleh bahwa:

\begin{tabular}{|l|c|r|r|r|}
\multicolumn{5}{|c|}{ Model Summary } \\
\hline Model & $\mathrm{R}$ & $\begin{array}{c}\mathrm{R} \\
\text { Square }\end{array}$ & $\begin{array}{c}\text { Adjusted R } \\
\text { Square }\end{array}$ & $\begin{array}{c}\text { Std. Error of } \\
\text { the Estimate }\end{array}$ \\
\hline 1 & $.672^{\mathrm{a}}$ & .452 & .421 & 4655.97011 \\
\hline
\end{tabular}

a. Predictors: (Constant), Tingkat Industri

Berdasarkan table diatas terlihat bahwa terdapat pengaruh tingkat industry dengan angka pengangguran. Sesuai dengan teori yang dikemukakan oleh Theodossiou 
dan Zarotiadis (2010) yang menyatakan bahwa di daerah yang kurang berkembang pengangguran berpengaruh negatif terhadap penyerapan tenaga kerja dikarenakan pengangguran tersebut memiliki dampak merugikan yang parah pada tenaga kerja lokal. Hanya saja pengaruh tingkat pengangguran terhadap penyerapan tenaga kerja sektor industri di kasus Indonesia ini adalah tidak signifikan. Hal yang kemungkinan dapat menjelaskan adalah bahwa perubahan pada tingkat pengangguran ternyata tidak berdampak terhadap sektor industri melainkan pada sektor-sektor yang lain. Kenaikan atau penurunan pengangguran biasanya akan lebih banyak mempengaruhi penyerapan tenaga kerja di sektor informal, mengingat sektor informal adalah merupakan katub pengaman bagi perekonomian ketika kondisi perekonomian kurang baik atau pengangguran tinggi. Sehingga dengan kata lain, penurunan tingkat pengangguran akan menaikkan penyerapan tenaga kerja di sektor informal dan bukan pada penyerapan tenaga kerja di sektor industri mengingat cukup sulitnya untuk masuk ke dalam sektor industri dibandingkan dengan sektorsektor yang lain, seperti sektor informal.

\section{KESIMPULAN}

Berdasarkan analisis data yang dilakukan, maka kesimpulan yang diperoleh adalah: Ada korelasi antara variabel tingkat industri dengan pengangguran sebesar 0,452 atau $45,2 \%$. Artinya hubungan koefisien korelasi adalah kuat.

\section{DAFTAR PUSTAKA}

Arsyad,L.(2010). Ekonomi Pembangunan, Edisi 5. Yogyakarta: UPP STIM YKPN Yogyakarta.

Baltagi,B. (2005).Ekonometrik Analysis Of Panel Data, Third Edition John Wiley\&Son Junaidi,J;

Hardiani,H. (2009). Dasar-DasarTeori Ekonomi Kependudukan. Jakarta.
Hamada Prima Junaidi, J. (2015). Bentuk Fungsional Regresi Linear (Aplikasi Model dengan Program SPSS). Jambi. Fakultas Ekonomi dan Bisnis

Kuncoro, M. (2006). Ekonomika Pembangunan.Teori,Masalah dan Kebijakan.

Edisikeempat.UPP.STIM.YKPN

Yogyakarta.

Karib, Abdul MS. (2012). Analisis Pengaruh Produksi, Investasi dan Unit Usaha Terhadap Penyerapan Tenaga Kerja Pada Sektor Industri Sumatera Barat. Jurnal Manajemen Dan Kewirausahaan, Volume 3, Nomor 3, September 2012 Issn : 2086-5031. Universitas Andalas. Padang.

Munasriah. (2015). Pengaruh Jumlah Unit Usaha dan Investasi Terhadap Penyerapan Tenaga Kerja Pada Industri Kecil di Kabupaten Wajo. Tesis. Fakultas Ekonomi dan Bisnis. UniversitasHasanuddin.Makasar

Prabandana, R. (2015). Pengaruh Modal, Nilai Produksi dan Tingkat Upah Terhadap Penyerapan Tenaga Kerja Industri Kecil di Kabupaten Sukoharjo. Fakultas Ekonomi dan Bisnis. Universitas Muhammadiyah. Surakarta

Squire, Lyn. (1992). Kebijakan Kesempatan Kerja di Negeri-Negeri Sedang Berkembang: Sebuah Survei, Masalah-Masalah dan Bukti-Bukti, Pustaka Bradjaguna, Jakarta.

Simanjuntak, J. Payaman. (2010). Pengantar Ekonomi Sumber Daya Manusia. Jakarta: Lembaga Penerbit Fakultas Ekonomi Universitas Indonesia.

Sukirno,S.(2002). Pengantar Teori Makroekonommi.Jakarta:PT.Raja Grafindo Persada 